\title{
INFLUENCE OF INTRAOPERATIVE BLOOD SALVAGE ON SURGERY FOR SCOLIOSIS
}

\author{
INFLUÊNCIA DA RECUPERAÇÃO INTRAOPERATÓRIA DE SANGUE EM CIRURGIAS PARA \\ ESCOLIOSE
}

\section{INFLUENCIA DE LA RECUPERACIÓN INTRAOPERATORIA DE LA SANGRE EN CIRUGÍA PARA LA ESCOLIOSIS}

\author{
Paulo Cesar Almeida ${ }^{4}$, Luciana Maria de Barros Carlos ${ }^{5}$, Saulo Rabelo Lima Verde ${ }^{2}$ \\ 1. Hospital Infantil Albert Sabin (HIAS), Orthopedics and Traumatology Service, Fortaleza, CE, Brazil. \\ 2. Hospital Geral de Fortaleza (/HGF), Orthopedics and Traumatology Service, Fortaleza, CE, Brazil \\ 3. Hospital Instituto Dr. José Frota (IJF), Orthopedics and Traumatology Service, Fortaleza, CE, Brazil. \\ 4. Universidade Estadual do Ceará (UECE), Center for Health Sciences (CCS), Fortaleza, Ceará, CE, Brazil.
}

José Alberto Alves Oliveira ${ }^{1,2}$, Fernando Antônio Mendes Façanha Filmo ${ }^{3}$, Samuel Ximenes Feijão ${ }^{1,2}$, Francisco Valmir Fernandes 2 ,

5. Centro de Hematologia e Hemoterapia do Ceará (Hemoce), Fortaleza, Ceará, CE, Brazil.

\begin{abstract}
Objective: To evaluate the effectiveness of intraoperative blood salvage (IBS) in reducing allogeneic transfusion in patients undergoing surgery for scoliosis. Methods: Retrospective case-control study with 69 patients who underwent surgical treatment for scoliosis correction from August 2008 to December 2014 in a teaching hospital. We used the IBS in 43 patients and it was not used in 26 . The groups were compared according to the medical records, and the data were processed on SPSS 20.0. For the associations between the variable IBS and non-IBS and the independent variables we applied the $X^{2}$ and the likelihood ratio tests, and the strength of which was calculated by their $95 \% \mathrm{Cl}$. The means were compared by Student's t and Mann-Whitney tests. The confidence level was 0.05 . Results: There were no significant differences between groups with the variables age, sex, preoperative weight, postoperative blood drainage and surgical time. There was a significant reduction of intraoperative allogeneic transfusion in the IBS group submitted to posterior arthrodesis compared with the control group, with no difference in the transfusion of red blood cells between the two groups postoperatively. In the 24 patients who underwent combined arthrodesis, there was no significant difference in allogeneic transfusion in the intra- and postoperative periods between the groups. Conclusion: The system proved to be effective in reducing allogeneic transfusion during surgery in patients undergoing posterior arthrodesis for scoliosis, but it was not effective in reducing allogeneic transfusion in the intra- and postoperative periods of those undergoing combined arthrodesis.
\end{abstract}

Keywords: Spinal fusion; Scoliosis; Blood transfusion, autologous; Operative blood salvage; Erythrocytes.

RESUMO

Objetivo: Avaliar a eficácia da recuperação intraoperatória de sangue (RIOS) na redução da transfusão alogênica em pacientes submetidos à cirurgia para escoliose. Métodos: Estudo retrospectivo de caso-controle, com 69 pacientes submetidos a tratamento cirúrgico corretivo para escoliose, de agosto de 2008 a dezembro de 2014, em hospital-escola. Utilizou-se a RIOS em 43 pacientes e não foi usada em 26. Os grupos foram comparados conforme os prontuários, e os dados foram processados no SPSS 20.0. Nas associações entre a variável RIOS e não-RIOS e as variáveis independentes aplicaram-se os testes do $X^{2}$ e de razão de verossimilhança, sendo a força dessas calculada pelo seu IC de 95\%. As médias foram comparadas pelos testes t de Student e de Mann-Whitney. O nível de confiança foi 0,05. Resultados: Não houve diferenças significativas entre os grupos com as variáveis idade, sexo, peso pré-operatório, drenagem sanguínea pós-operatória e tempo cirúrgico. Evidenciou-se redução significativa da transfusão alogênica intraoperatória no grupo RIOS submetido à artrodese posterior em comparação com o grupo-controle, sem diferença na transfusão de concentrado de hemácias entre os dois grupos no pós-operatório. Nos 24 pacientes submetidos à artrodese combinada, não houve diferença significativa na transfusão alogênica no intra e no pós-operatório entre os grupos. Conclusão: O sistema revelou-se eficaz em reduzir a transfusão alogênica no intraoperatório de pacientes submetidos à artrodese posterior para escoliose, mas não foi eficaz em reduzir a transfusão alogênica no intra e no pós-operatório daqueles submetidos à artrodese por via combinada.

Descritores: Fusão vertebral; Escoliose; Transfusão de sangue autóloga; Recuperação de sangue operatório; Eritrócitos.

\section{RESUMEN}

Objetivo: Evaluar la eficacia de la recuperación de sangre intraoperatoria (RSI) en la reducción de la transfusión alogénica en pacientes sometidos a cirugía para la escoliosis. Métodos: Estudio retrospectivo de casos y controles, con 69 pacientes sometidos a cirugía correctora de la escoliosis, entre agosto de 2008 y diciembre de 2014 en un hospital universitario. Se utilizó la RSI en 43 pacientes y no se utilizó en 26. Los grupos se compararon según los datos de los registros médicos y los datos fueron procesados en el programa SPSS 20.0. En las asociaciones entre la variable RSI y no-RSI y las variables independientes se aplicaron las pruebas de x2 y la razón de verosimilitud, siendo la fuerza de éstas calculada por su IC de 95\%. Los promedios se compararon mediante la 
pruebas de la t de Student y de Mann-Whitney. El nivel de confianza fue de 0,05. Resultados: No se observaron diferencias significativas entre los grupos en las variables edad, sexo, peso preoperatorio, drenaje de sangre postoperatoria y tiempo quirúrgico. Se mostró una reducción significativa de la transfusión alogénica durante la cirugía en el grupo RSI sometido a la artrodesis posterior en comparación con el grupo de control, sin diferencia en la transfusión de células rojas de la sangre entre los dos grupos después de la operación. En los 24 pacientes que se sometieron a la artrodesis combinada, no hubo diferencia significativa en la transfusión alogénica en el intra y postoperatorio entre los grupos. Conclusión: El sistema ha demostrado su eficacia en la reducción de la transfusión alogénica durante la cirugía en pacientes sometidos a artrodesis posterior para la escoliosis, pero no fue efectivo en la reducción de la transfusión alogénica en el intra y postoperatorio en los que se sometieron a la artrodesis por vía combinada.

Descriptores: Fusión vertebral; Escoliosis; Transfusión de sangre autóloga; Recuperación de sangre operatoria; Eritrocitos.

\section{INTRODUCTION}

One of the main causes of morbidity in surgeries to correct spinal deformities is blood loss. Arthrodeses of the spine are commonly associated with high volumes of bleeding (650 to $2.839 \mathrm{ml})$. $^{1-3}$

This is a common problem, particularly in arthrodeses involving more than one level. Greater blood loss may require transfusions of blood derivatives. Although the safety screening of blood bags has improved considerably in recent years, there are still potential risks of transfusion reactions and alloimmunization. Furthermore, there is also the risk of contracting infectious diseases: human immunodeficiency virus (HIV) 1: 1.930.000, hepatitis B 1: 137.000, Hepatitis C 1: 1.000 .000 and bacterial sepsis. ${ }^{2,4}$

These risks, although small, have prompted surgeons to look for ways of reducing the number of allogeneic blood transfusions. ${ }^{4}$ There are various preoperative and intraoperative techniques reported in the literature to minimize blood loss and the need for a blood transfusion. These include normovolemic hemodilution; hypotensive anesthesia; longer procedures; preoperative autologous blood donation; intraoperative blood salvage (IBS); Cell Saver in the North American literature; autologous growth factor (AGF); recombinant factor VIIA ( $\mathrm{rFVIIa)} \mathrm{and} \mathrm{antifibrinolytic} \mathrm{agents} \mathrm{(aprotinin,} \mathrm{tranexamic}$ acid and aminocaproic acid). ${ }^{2}$

IBS is an intraoperative blood cell salvage system that collects the blood from the surgical field by aspiration, then washes and filters the residues, such as cellular and biochemical remains. After the filtering process, the patient's erythrocytes are reinfused back into the patient. ${ }^{3}$

This method can, occasionally, eliminate the need to collect blood from the patient prior to surgery for an autologous infusion during surgery, as well as the need for allogeneic transfusion. Other advantages are: the absence of transmission of viral diseases, reduced risk of alloimmunization, normal concentration of potassium, considering the fact that the cells are infused at room temperature. ${ }^{4}$ It is also a good alternative for patients who refuse to receive blood donations due to religious beliefs. ${ }^{1}$

Despite the advantages of this method, it is not clear whether its use decreases the need for allogeneic transfusions in surgeries for scoliosis; some studies have shown a positive association, while others have not.

The present study aims to evaluate the efficacy of intraoperative blood salvage as a method of reducing allogeneic transfusion in patients submitted to arthrodesis of the vertebral spine for corrective surgical treatment of scoliosis.

\section{MATERIALS AND METHODS}

This is a case-control study with a sample comprised of 69 patients submitted to surgical treatment for scoliosis at the orthopedic service of Hospital Geral de Fortaleza (HGF) from August 2008 to December 2014. All the surgeries were performed by the same two spine surgeons, operating in the same place, under similar conditions and with similar operating techniques.

More than one model of intraoperative blood salvage system was used during the period of analysis, due to the competitive bidding processes for the acquisition of the system in the public service (2009-2010: Dideco Compact Avanced; 2011-2012: Dideco Electa Essential Concept; 2013: Fresenius C.A.T.S e 2014: Autolog Medtronic).
The device was used in 43 patients, and was not used in 26 patients (control group). The patients were not randomized, but each surgeon decided independently whether to use the IBS or not.

Of a universe of 72 patients submitted to corrective surgical treatment for scoliosis at the abovementioned institution, only 69 took part in the research, i.e. those who met the following inclusion criteria: individuals of both sexes, diagnosed and operated on by the same team of spine surgeons at the orthopedic center of the HGF from August 2008 to December 2014, as well as those who underwent procedures in which only 3 rd generation materials were used (pedicle hooks and screws) as surgical instrumentation. The following were excluded from the sample: patients whose preoperative data showed a history of previous surgical procedure on the spine, including revision surgeries; those with a history of hemostasis disorders, low platelet counts $(<100.000)$, changes in prothrombin time (PT)/ international normalized ratio (INR), activated partial thromboplastin time (APTT); thromboembolic events prior to surgery, or a family history of thromboembolism, and those whose religious beliefs do not allow blood transfusion (Jehovah's Witnesses).

Pre-donated autologous blood, intraoperative isovolumetric hemodilution or erythropoietin (EPO) was not used in any patient, either pre- or postoperatively. Aminocaproic acid, at an attack dose of $100 \mathrm{mg} / \mathrm{Kg}$ (maximum dose of 6 grams during anesthetic induction, was used in twenty patients (12 who used IBS and 8 who did not). All the patients were placed in the ventral decubitus position on the operating table, leaving the abdomen free, to reduce abdominal venous pressure. Hypotensive anesthesia was used during all the surgeries, to maintain a mean arterial pressure of around $60 \mathrm{mmHg}$ and during the spine reduction process at around $80 \mathrm{mmHg}$ to avoid ischemic lesion of the spinal cord. The parameters for blood transfusion include signs of anemia: decreased urine output $<30 \mathrm{ml} / \mathrm{h}$ determined by bladder catheter, increased heart rate ( $>100$ beats $/ \mathrm{min}$ ) and hypotension $(<100 \mathrm{mmHg}$ systolic arterial pressure) refractory to volemic expansion and a hemoglobin level of less than $8 \mathrm{~g} / \mathrm{dl}$ by gasometry, or a hemoglobin level of less than $7 \mathrm{~g} / \mathrm{dl}$, independently of the signs or symptoms of anemia. The decision to perform allogeneic blood transfusion during surgery was made jointly between the surgeon and the anesthetist.

Intraoperative via Somato-Sensitive Evoked Potentials and Motors, only the awakening test.

All the operative lesions were closed with two suction drains, one indwelling, the other subcutaneous. The drains were removed when the 24-hour drainage was less than $100 \mathrm{ml}$, which occurred on around the 3rd postoperative day.

In the postoperative period, the patients remained in the intensive care unit for around 48 hours. In this period, the same blood transfusion parameters were adopted, the transfusion decision being taken jointly between the surgeon and the intensive care doctor. After this period, the patient was discharged to the ward, with the transfusion decision being made by the surgeon responsible.

In cases with curves of more than 100 degrees and rigid (correction less than $50 \%$ in $\mathrm{x}$-rays in lateral inclination), it was decided on a combined approach (anterior and posterior). The first was performed to promote more flexibility of the curve for the posterior arthrodesis, using only $3^{\text {rd }}$ generation materials (pedicle hooks and screws) as surgical instrumentation. The two procedures were conducted in different stages, with a time 
interval of fifteen days between them, with the patients remaining in hospital during this period.

The groups were compared according to the following data from the medical records: sex, age at surgery, preoperative weight, duration of the surgical procedure in minutes, intraoperative use of IBS, volume of postoperative blood drainage, volume of blood reinfused by IBS, postoperative levels of allogeneic blood transfused, and access route, whether posterior or combined (anterior and posterior).

The data were processed in SPSS 20.0 license no. 10101131007, when the mean, median and standard deviation were calculated. In the associations between the variable IBS and Non-IBS, and the independent variables, the $\chi^{2}$ and verisimilitude ratio tests were performed, and the force of these calculated by their $95 \% \mathrm{Cl}$. The comparisons of the means of the variables, according to the case and control groups, were performed by the Student t and Mann-Whitney tests. The level of confidence was set at 0.05 .

According to Resolution 466/2012 of the National Health Council, the present study was approved by the Research Ethics Committee of the abovementioned institution, with opinion no. 1.444.279. All the adult participants signed the Informed Consent Form, while minors signed the Informed Assent Form and their legal guardians signed the Informed Consent Form.

\section{RESULTS}

The mean age of the 69 patients who participated in the research was $19.22 \pm 6.78$ years in the control group and $18.75 \pm 5.78$ years in the IBS group ( $p>0.05)$.

In the 24 patients submitted to arthrodesis by the combined approach, the mean age was $21.71 \pm 8.29$ years in the control group and $17.88 \pm 6.46$ in the group submitted to intraoperative blood salvage $(p>0.05)$. There were no significant differences between the groups in relation to the other variables: sex, preoperative weight, postoperative blood drainage, and surgery time. The mean intraoperative volume of blood salvaged and reinfused in the patient was $754.69 \pm 521.98 \mathrm{ml}$ in the group that used the intraoperative blood salvage system with arthrodesis by the combined approach (Table 1).

Descriptive analysis was performed, to summarize the characteristics of the patients and of the surgical procedure by the combined approach. Of the 24 patients operated on by the combined approach, 13 used IBS and 11 did not (control group) (Table 1).

Among the patients submitted to the combined approach, there was no significant difference between the groups in the number of units of packed red blood cells transfused, whether intra- or postoperatively $(p>0.05)$. (Table 1$)$

Evaluating the 45 patients submitted to arthrodesis by the posterior approach alone, it was observed that the average age of these patients was $17.4 \pm 4.9$ years in the control group, and $19.1 \pm 5.52$ years in the IBS group. Therefore, there was no difference between the two $(p>0.05)$. Moreover, there were also no differences for the other variables, such as sex, preoperative weight and postoperative drainage. The mean interoperative volume of blood salvaged and reinfused in the patient was $696.1 \pm 410.8 \mathrm{ml}$ in the group that used intraoperative blood salvage (Table 2).

In the patients who used the intraoperative blood salvage system, it was found that there was less intraoperative allogeneic blood transfusion compared with the control group $(p=0.002)$. In the postoperative period, although many patients in the IBS group did not receive packed red blood cells compared with the other group, no difference was observed in the association ( $p>0.05$ ) (Table 2).

Evaluating the hematimetric levels of the patients between the groups submitted to arthrodesis by the combined approach or by the posterior approach alone, it was seen that there was no difference between the final values of hemoglobin and hematocrit (on the $1^{\text {st }}$ and $3^{\text {rd }}$ days postoperative as well as at hospital discharge) ( $p>0.05)$ (Table 3).
Table 1. Comparison of clinical and surgical characteristics between the groups submitted to arthrodesis by the combined approach (anterior and posterior).

\begin{tabular}{|c|c|c|c|}
\hline & $\begin{array}{c}\text { Non-IBS } \\
(n=11 / 45.8 \%)\end{array}$ & $\begin{array}{c}\text { IBS } \\
(n=13 / 54.2 \%)\end{array}$ & p \\
\hline Age(year) & $21.71 \pm 8.29$ & $17.88 \pm 6.46$ & $0.228^{3}$ \\
\hline Sex & & & $0.851^{1}$ \\
\hline Female & $8(47.1 \%)$ & $9(52.9 \%)$ & \\
\hline Male & $3(42.9 \%)$ & $4(57.1 \%)$ & \\
\hline Weight(kg) & $42.7 \pm 12.6$ & $46.5 \pm 9.8$ & $0.427^{2}$ \\
\hline \multicolumn{4}{|l|}{ Etiology } \\
\hline Congenital & 1 & 5 & \\
\hline Idiopathic & 8 & 8 & \\
\hline Neuromuscular & 2 & - & \\
\hline Syndromic & - & - & \\
\hline Postop drainage & $1241.82 \pm 446.82$ & $1183.08 \pm 403.12$ & $0.733^{3}$ \\
\hline $\begin{array}{l}\text { Vol. salvaged in } \\
\text { the intraop. }\end{array}$ & - & $754.69 \pm 521.98$ & \\
\hline Transfusion (op.) (U/p)* & & & $0.098^{4}$ \\
\hline 0 & $0(0 \%)$ & $1(100 \%)$ & \\
\hline 1 & $1(20 \%)$ & $4(80 \%)$ & \\
\hline 2 & $2(28.6 \%)$ & $5(71.4 \%)$ & \\
\hline 3 a 6 & $6(75.0 \%)$ & $2(25.0 \%)$ & \\
\hline $\begin{array}{c}\text { Transfusion } \\
\text { (postop.) }(\mathrm{U} / \mathrm{p})^{*}\end{array}$ & & & $0.053^{4}$ \\
\hline 0 & $3(42.9 \%)$ & $4(57.1 \%)$ & \\
\hline 1 & $2(66.7 \%)$ & $1(33.3 \%)$ & \\
\hline 2 & $0(0 \%)$ & $5(100 \%)$ & \\
\hline 3 a 6 & $4(66.7 \%)$ & $2(33.3 \%)$ & \\
\hline Surgery time(min.) & $678.18 \pm 241.83$ & $593.07 \pm 111.64$ & $0.424^{3}$ \\
\hline
\end{tabular}

1-Chi Squared Test; 2-Student $t$ Test; 3-Mann-Whitney Test; 4- Verisimilitude ratio.

*Transfusion (op.) (U/p) number of units of packed red blood cells transfused per patient in the intraoperative period. Transfusion (post-op.) (U/p) number of units of packed red blood cells transfused per patient in the postoperative period.

Table 2. Comparison of clinical and surgical characteristics between the two groups submitted to arthrodesis by the posterior approach.

\begin{tabular}{c|c|c|c}
\hline & $\begin{array}{c}\text { Non-IBS } \\
\text { (n= 15/33. 3\%) }\end{array}$ & $\begin{array}{c}\text { IBS } \\
\text { (n= 30/66. 7\%) }\end{array}$ & $\mathbf{p}$ \\
\hline Age(years) & $17.4 \pm 4.9$ & $19.1 \pm 5.52$ & $0.311^{1}$ \\
\hline Sex & & & $0.741^{2}$ \\
\hline Female & $13(32.5 \%)$ & $27(67.5 \%)$ & \\
\hline Male & $2(40 \%)$ & $3(60 \%)$ & \\
\hline Weight $(\mathrm{kg})$ & $47.8 \pm 8.8$ & $53.6 \pm 13.0$ & $0.127^{1}$ \\
\hline Etiology & & & \\
\hline Congenital & - & 1 & \\
\hline Idiopathic & 15 & - & \\
\hline Neuromuscular & - & 27 & \\
\hline Syndromic & - & $1183.08 \pm 403.12$ & $0.733^{3}$ \\
\hline Postop. drainage & $1241.82 \pm 446.82$ & 112 &
\end{tabular}

Vol. salvaged in the intraop. (ml)

Transfusion (op.) $(\mathrm{U} / \mathrm{p})^{*}$

\begin{tabular}{c|c|c|c}
$(\mathrm{U} / \mathrm{p})^{*}$ & & & \\
\hline 0 & $3(16.7 \%)$ & $15(83.3 \%)$ & \\
\hline 1 & $2(15.4 \%)$ & $11(84.6 \%)$ & \\
\hline 2 & $4(57.1 \%)$ & $3(42.9 \%)$ & \\
\hline 3 a 9 & $6(85.7 \%)$ & $1(14.3 \%)$ & \\
\hline $\begin{array}{c}\text { Transfusion } \\
\text { (postop.) }(\mathrm{U} / \mathrm{p})^{*}\end{array}$ & & & $0.301^{2}$ \\
\hline 0 & $5(23.8 \%)$ & $16(76.2 \%)$ & \\
\hline 1 & $5(50.0 \%)$ & $5(50.0 \%)$ & \\
\hline 2 & $3(27.3 \%)$ & $8(72.7 \%)$ & \\
\hline $3-9$ & $2(66.7 \%)$ & $1(33.3 \%)$ & \\
\hline Surgery time (min.) & $357.0 \pm 74.4$ & $344.8 \pm 67.7$ & $0.585^{1}$ \\
\hline
\end{tabular}

1-Student $t$ test; 2- Verisimilitude ratio; 3- Mann-Whitney test.

*Transfusion (op.) (U/p) number of units of packed red blood cells transfused per patient in the intraoperative period. Transfusion (post-op.) (U/p) number of units of packed red blood cells transfused per patient in the postoperative period. 


\section{DISCUSSION}

In a meta-analysis published in $2010,^{2}$ the results were analyzed evaluating the effect of intraoperative blood salvage during spine surgery based on three retrospective studies, all sharing poor methodological quality according to these authors. According to this systematic review, there are few studies in the literature to support the use or not of this system in elective surgery of the vertebral spine.

In a retrospective study, ${ }^{5}$ the predictors of allogeneic blood transfusion in patients diagnosed with adolescent idiopathic scoliosis were evaluated, based on a North American database with 28.080 patients. Of these, 5.153 underwent allogeneic blood transfusion, while 22.927 did not. According to these authors, intraoperative blood salvage was not capable of avoiding allogeneic blood transfusion.

Other researchers ${ }^{6}$ have evaluated the benefit of IBS in surgery for scoliosis comparing two groups; one with 58 patients, in which this method was used, and another with 37 patients in which it was not used. Those authors found that the volume of blood that needs to salvaged by IBS to justify its use in surgery is at least $500 \mathrm{ml}$. In view of this, the surgeon may use this figure to better estimate whether there is a need to use this system. If less than $500 \mathrm{ml}$ of blood is expected, the study shows that the cost of using the device is not justified. Furthermore, they conclude that the patients in the case group had the same chance of receiving allogeneic transfusions as the control group.

In our study, the volume of blood salvaged by IBS and reintroduced into the patient was around $754 \mathrm{ml}$ in those undergoing arthrodesis by the combined approach, and 696ml in those undergoing arthrodesis by the posterior approach alone.

In their retrospective study, ${ }^{7}$ the authors evaluated the efficacy of IBS in patients with idiopathic scoliosis submitted to surgical

Table 3. Comparison of hemoglobin and hematocrit levels in the pre- and postoperative periods, between the two groups submitted to combined arthrodesis and by the posterior approach.

\begin{tabular}{|c|c|c|c|}
\hline & $\begin{array}{c}\text { Non-IBS } \\
(n=43 / 62.3 \%)\end{array}$ & $\begin{array}{c}\text { IBS } \\
(n=26 / 37.7 \%)\end{array}$ & $\mathbf{p}^{*}$ \\
\hline \multicolumn{4}{|l|}{ Combined approach } \\
\hline \multicolumn{4}{|l|}{ Hemoglobin (g/dl) } \\
\hline Preoperative & $24.83 \pm 1.59$ & $25.34 \pm 2.08$ & 0.536 \\
\hline Day 1 Postoperative & $10.68 \pm 1.75$ & $10.71 \pm 1.46$ & 0.960 \\
\hline Day 3 Postoperative & $18.72 \pm 3.57$ & $19.51 \pm 0.79$ & 0.632 \\
\hline Hospital discharge & $9.80 \pm 2.03$ & $10.08 \pm 1.47$ & 0.696 \\
\hline \multicolumn{4}{|l|}{ Hematocrit (\%) } \\
\hline Properative & $71.21 \pm 5.47$ & $77.05 \pm 4.80$ & 0.015 \\
\hline Day 1 Postoperative & $57.30 \pm 3.41$ & $61.69 \pm 5.89$ & 0.061 \\
\hline Day 3 Postoperative & $54.73 \pm 10.60$ & $58.80 \pm 3.39$ & 0.439 \\
\hline Hospital discharge & $28.88 \pm 5.64$ & $30.14 \pm 4.77$ & 0.558 \\
\hline \multicolumn{4}{|l|}{ Posterior approach } \\
\hline \multicolumn{4}{|l|}{ Hemoglobin(g/dl) } \\
\hline Properative & $13.11 \pm 1.27$ & $13.35 \pm 1.11$ & 0.514 \\
\hline Day 1 Postoperative & $8.08 \pm 1.30$ & $8.93 \pm 1.54$ & 0.084 \\
\hline Day 3 Postoperative & $8.42 \pm 1.80$ & $8.78 \pm 1.40$ & 0.529 \\
\hline Hospital discharge & $8.61 \pm 1.52$ & $9.08 \pm 1.63$ & 0.364 \\
\hline \multicolumn{4}{|l|}{ Hematocrit (\%) } \\
\hline Preoperative & $39.26 \pm 3.54$ & $39.67 \pm 3.15$ & 0.698 \\
\hline Day 1 Postoperative & $23.76 \pm 3.32$ & $26.52 \pm 4.76$ & 0.059 \\
\hline Day 3 Postoperative & $24.69 \pm 4.95$ & $25.82 \pm 4.08$ & 0.479 \\
\hline Hospital discharge & $25.05 \pm 4.22$ & $26.97 \pm 5.09$ & 0.218 \\
\hline
\end{tabular}

$\mathrm{p}^{*}$ by the Student $t$ test treatment. There were two groups, one with sixteen patients, in which the system was used, and another with seventeen, in which it was not used. The authors observed no difference between groups in the evaluation of allogeneic blood transfusion. According to them, the fact that use of hypotensive anesthesia in all the patients was linked to a shorter surgery time, compared with other cases series, may have been responsible for decreasing the efficacy of intraoperative blood salvage in that study.

However, in a particular study, ${ }^{8}$ when evaluating the efficacy of IBS in 54 patients with idiopathic scoliosis submitted to posterior arthrodesis with segment instrumentation, it was demonstrated that the use of IBS was closely associated with a reduction in intraoperative and perioperative allogeneic blood transfusion, comparing the group that used the device (21 patients) with those who did not use it (33 patients).

According to that source ${ }^{8}$ the divergent conclusions of different studies in relation to the efficiency of the intraoperative blood salvage system can be explained by the way in which the IBS is handled, as well as the perioperative strategies of blood management. The abovementioned authors report a uniform perioperative blood management strategy: no patient in their study was submitted to pre-donation of autologous blood or isovolumetric hemodilution, or received intraoperative antifibrinolytic medications. They used only hypotensive anesthesia.

In another study, ${ }^{3}$ a perioperative blood approach similar to that of the authors cited above was adopted, ${ }^{8}$ when evaluating 45 patients submitted to posterior arthrodesis of the spine with segmental instrumentation for adolescent idiopathic scoliosis with or without intraoperative blood salvage. As they demonstrated, there was less need for perioperative allogeneic blood transfusion in the group of patients who used IBS (23 patients) than in the control group (22 patients).

Through a system similar to that of two recently-mentioned studies, other researchers ${ }^{9}$ have retrospectively evaluated children and adolescents of school age with scoliosis submitted to posterior arthrodesis of the spine with segmental instrumentation. They evaluated two groups, in which IBS was used (67 patients) and a control group (180 patients). It was perceived that the use of the erythrocyte recovery system significantly reduced the need for intraoperative allogeneic transfusion, but did not manage to reduce overall intraoperative allogeneic blood transfusion.

In our retrospective study, a significant reduction in intraoperative allogeneic blood transfusion was identified in the group of patients treated with intraoperative blood salvage, and who underwent arthrodesis via the posterior approach with segmental instrumentation, compared with the control group. However, there was no difference between the two groups in terms of transfusion of packed red blood cells in the postoperative periods. In the 24 patients who underwent arthrodesis via the combined approach (anterior and posterior), there was no significant decrease in allogeneic blood transfusion, whether intraoperative or postoperative.

There was no significant difference in hematimetric levels (hemoglobin and hematocrit), on the first and third postoperative days, as well as at discharge from hospital, between patients who used IBS, whether by the combined approach or the posterior approach alone, compared with the control group.

This study corroborates the point of view mentioned, ${ }^{8}$ whereby the divergent conclusions in different studies, in terms of the efficacy of the intraoperative blood salvage system, can be explained by the form of handling the intraoperative blood salvage, and also by the perioperative blood management strategies used. Our study did not use pre-donation of autologous blood, isovolumetric hemodilution, only hypotensive anesthesia and in some cases, the antifibrinolytic agent aminocaproic acid (in 12 patients who used IBS and in 8 who did not).

In a prospective, randomized study ${ }^{4}$, the safety and efficacy of the intraoperative cell salvage system in decreasing the need for allogeneic blood transfusions was determined in a cohort of 110 patients with scoliosis submitted to posterior arthrodesis 
with segmental instrumentation of the spine. Unlike other studies, this one adopted as blood management measures, besides hypotensive anesthesia, the administration of erythropoietin $(10.000$ Ul subcutaneous) daily after surgery, for one week, as well as iron supplementation during the same period. A difference was seen in the intraoperative and perioperative transfusion in the group of patients who used IBS, compared with the control group.

Our research presented the limitations inherent to a retrospective study, such as the non-randomization of patients and the presence of confounding variables. In the view of the authors of this article, more studies are needed, particularly at national level, to evaluate not only the efficacy of IBS, but also its cost-effectiveness in public health.

\section{CONCLUSIONS}

Based on the present study, it was observed that intraoperative blood salvage was effective in reducing the intraoperative transfusion of allogeneic blood in patients submitted to posterior arthrodesis with segment instrumentation for the treatment of scoliosis. However, IBS did not prove effective in reducing allogeneic transfusion, both intraoperative and postoperative, in patients submitted to arthrodesis by the combined approach.

All the authors declare no potential conflict of interest relating to this article.

CONTRIBUTIONS OF THE AUTHORS: Each author made an individual and significant contribution to the development of the manuscript. JAAO, SXF and SRLV were the main contributors to the writing of the manuscript. FVF and SRLV performed the surgery, followed up the patients and gathered the clinical data. JAAO, PCA and LMBC evaluated the data from the statistical analysis. FAMFF, JAAO, SXF, SRLV, PCA, FVF and LMBC performed the literature review, and revised the manuscript. All the authors contributed to the intellectual concept of the study.

\section{REFERENCES}

1. Joseph SA Jr, Berekashvili K, Mariller MM, Rivlin M, Sharma K, Casden A, et al. Blood conservation techniques in spinal deformity surgery: a retrospective review of patients refusing blood transfusion. Spine (PhilaPa 1976). 2008;33(21):2310-5.

2. Elgafy $H$, Bransford RJ, McGuire RA, Dettori JR, Fischer D. Blood loss in major spine surgery: are there effective measures to decrease massive hemorrhage in major spine fusion surgery? Spine (PhilaPa 1976). 2010;35(Suppl 9):S47-56.

3. Ersen O, Ekıncı S, Bılgıc S, Kose O, Oguz E, Sehırlıoglu A. Posterior spinal fusion in adolescent idiopathic scoliosis with or without intraoperative cell salvage system: a retrospective comparison. Musculoskelet Surg. 2012;96(2):107-10.

4. Liang J, Shen J, Chua S, Fan Y, Zhai J, Feng B, et al. Does intraoperative cell salvage system effectively decrease the need for allogeneic transfusions in scoliotic patients undergoing posterior spinal fusion? A prospective randomized study. Eur Spine J. 2015;24(2):270-5

5. Yoshihara $H$, Yoneoka D. Predictors of allogeneic blood transfusion in spinal fusion for pediatric patients with idiopathic scoliosis in the United States, 2004-2009. Spine (PhilaPa 1976). 2014;39(22):1860-7.

6. Weiss JM, Skaggs D, Tanner J, Tolo V. Cell Saver: is it beneficial in scoliosis surgery? J Child Orthop. 2007;1(4):221-7.

7. Akgül T, Dikici F, Ekinci M, Buget M, Polat G, Sar C. The efficacy of cell saver method in the surgical treatment of adolescent idiopathic scoliosis. Acta OrthopTraumatol Turc. 2014;48(3):303-6.

8. Bowen RE, Gardner S, Scaduto AA, Eagan M, Beckstead J. Efficacy of intraoperative cell salvage systems in pediatric idiopathic scoliosis patients undergoing posterior spinal fusion with segmental spinal instrumentation. Spine (PhilaPa 1976). 2010;35(2):246-51.

9. Miao YL, Ma HS, Guo WZ, Wu JG, LiuY, Shi WZ, et al. The efficacy and cost-effectiveness of cell saver use in instrumented posterior correction and fusion surgery for scoliosis in school-aged children and adolescents. PLoSOne. 2014;9(4):e92997. 